\title{
Exploring and Applying a Socially Progressive Hermeneutical Lens in Hindu Thought
}

\author{
Akshay Gupta
}

Citation: Gupta, Akshay. 2021. Exploring and Applying a Socially Progressive Hermeneutical Lens in Hindu Thought. Religions 12: 595. https://doi.org/10.3390/rel12080595

Academic Editor: David

Peter Lawrence

Received: 16 June 2021

Accepted: 29 July 2021

Published: 2 August 2021

Publisher's Note: MDPI stays neutral with regard to jurisdictional claims in published maps and institutional affiliations.

Copyright: (C) 2021 by the author. Licensee MDPI, Basel, Switzerland. This article is an open access article distributed under the terms and conditions of the Creative Commons Attribution (CC BY) license (https:// creativecommons.org/licenses/by/ $4.0 /)$.
Faculty of Divinity, University of Cambridge, Cambridge CB3 9BS, UK; akshayg95@yahoo.com or ag2095@cam.ac.uk

\begin{abstract}
Hermeneutics is the theory and methodology of interpreting texts. In this paper, I describe and explore the implications of a hermeneutical lens that was utilized by the Caitanya Vaisnava theologian A.C. Bhaktivedanta Swami Prabhupāda (1896-1977 CE). My aims in doing so are to (1) contribute toward inter-religious reform within the International Society for Krishna Consciousness (ISKCON), which Prabhupāda founded in 1966, and to (2) further develop Hindu conceptual resources that can inspire societal change. I also apply Prabhupāda's hermeneutical lens to one narrative within the Bhāgavatapurāna (c. 9th to 10th century CE) and show how reading this narrative through this lens can de-emphasize certain patriarchal attitudes that are found within Hindu universes. Moreover, I demonstrate this lens' applicability within ISKCON. I conclude by showing how this lens can also be applied in some other Hindu contexts.
\end{abstract}

Keywords: hermeneutics; Caitanya Vaiṣnavism; ISKCON; Feminism

\section{Introduction}

In this paper, I describe and explore the significance of a particular hermeneutical lens that was utilized by A.C. Bhaktivedanta Swami Prabhupāda (1896-1977 CE), who is a theologian within the Caitanya Vaiṣnava tradition (henceforth Caitanya tradition). This Hindu devotional tradition is based on the life and the teachings of the Bengali saint Caitanya (1486-1534 CE) and is centered on cultivating intensely affective forms of devotional love toward Krṣna, whom the tradition views as the supremely personal God (Sardella 2012, pp. 182-83). I then discuss how this lens can facilitate religious reform by applying it in an exegesis of the Bhägavata Purāna (c. 9th century CE) (henceforth BhP), which is considered to be one of India's most influential sacred texts (Gupta and Valpey 2016, p. 1).

First however, it will be helpful to define the term "hermeneutics", as it is employed within some Anglophone contexts. In such contexts, hermeneutics is the theory and methodology of interpreting and understanding texts. Early use of the term in the late 18th and 19th centuries "referred strictly to rules for the interpretation of texts, particularly ancient texts" (Brown 2011, p. 113). More recently, it has been defined as "the act of interpretation that inquires into the ways in which meaning is formed in text and is also more broadly a philosophical inquiry into human existence" (Flood 2016, p. 150). There are various extant hermeneutical lenses and approaches. To begin with, there is "theological hermeneutics", which is the interpretation of religious texts that are regarded as sacred (Zimmermann 2015, pp. 72-97). Individuals can also employ "historical critical hermeneutics", or "the "historical-critical method" that seeks to understand the "historical origins and trajectory of a text" (Flood 2016, p. 154). Moreover, one can configure a feminist hermeneutical lens, which "develops theories of interpretation that specifically explore the relationship of power to 'meaning', and offers analyses that seek to empower women" (Amador 1998, p. 40).

It is also worth noting that in Hindu philosophy, modes of inquiry analogous to hermeneutics have been developed since as early as 200 BCE. The closest Indian equivalent 
of the term "hermeneutics" is mīmāmsa ("desiring to contemplate"), and it was first codified in Jaimini's Mìmāmssāsūtra (c. 200 BCE) and later developed by the exegetes Śabara (c. 3rd6th century CE) Kumārila Bhaț̣a (c. 5-7th century CE) and Prabhākara (c. 5-7th century $\mathrm{CE}$ ). It is worth noting that there are two systems of $m \bar{m} m \bar{a} m s \bar{a}$, namely, Pūrva Mīmāmssā and Uttara Mīmāṃsā (more commonly known as Vedānta) (Chakraborty 2018, p. 25). As Nirmalya Chakraborty explains, both of these systems "are concerned with explaining Vedic sentences and determining their meaning as well as their significance or import (tātparya)" (Chakraborty 2018, p. 25). One crucial distinction between these two systems is that Pūrva Mīmāmsā is concerned with the "investigation of the (logically preceding part of the Vedas (the Brāhmanas)", whereas Uttara Mīmāṃsā pertains to the "investigation of the (logically subsequent) part of the Veda (the Upanisads)" (Freschi 2018). Although both these systems of mimmāmsā have been immensely influential within India's intellectual history, it is beyond the scope of this paper to discuss them in greater depth. For a brief overview of Pūrva Mīmāmsa, see (Freschi 2018; Dudney 2018; Clooney 1990b), and for a brief history of Vedānta along with various explorations into different Vedāntic traditions, see (Maharaj 2020).

Given the plethora of hermeneutical lenses, both within and outside of Hindu thought, one may question why it is important to examine and analyze Prabhupāda's employment of his hermeneutical lens in particular, especially when similar hermeneutical lenses exist (Sherma and Sharma 2008; Fiorenza 2014), and when other thinkers, either within or outside of the Caitanya tradition, could be examined. For instance, there are other notable exegete-theologians within the Caitanya tradition such as Rūpa Gosvāmin (15-16th century CE), Jĩva Gosvāmin (15-16th century CE), and Baladeva Vidyabhūṣana (18th century CE), who have made contributions to the Caitanya tradition's hermeneutical philosophy and whose views shaped the views of later theologians with the tradition, such as Prabhupāda himself (see Gupta 2007; Okita 2014; Uskokov 2018).

My aims in focusing specifically on Prabhupāda and his hermeneutical lens are twofold. At the outset, I should note that it has been documented that Prabhupāda has made a number of statements concerning the role and the status of women, racial minorities such as blacks, and individuals of a lower caste. Such statements, though perhaps common to Prabhupāda's socio-historical context (20th century West Bengal), portray these groups in a negative light and have led to various problems within the International Society for Krishna Consciousness (ISKCON), the religious institution Prabhupāda founded in New York in 1966. Such statements have been described extensively (see Lorenz 2004 for Prabhupāda's comments on women; Deadwyler 2004, pp. 371-72 for his comments on racial minorities and lower caste individuals), and so I will not reiterate them here. However, I will briefly mention that it is well-documented that such statements have been uncritically received and internalized by many of Prabhupāda's direct students and present-day followers (Lorenz 2004, p. 124).

As I will later argue, I do not believe that mistreatment of women is justified when one understands Prabhupāda's hermeneutical lens and examines Prabhupāda's attitude towards women in his other teachings or in his personal dealings with women. While it is true that Prabhupāda did make certain statements that could be selectively interpreted in order to justify patriarchal attitudes, there are a variety of other factors that need to be taken into consideration when making judgements about how to apply Prabhupāda's teachings.

For these reasons, the first aim of this paper is to offer one corrective to the various problems that have affected ISKCON, and to put forth alternative readings of Prabhupāda's teachings that can be utilized by practitioners within ISKCON that do wish to adhere to a socially egalitarian vision of the world. My goal is not to argue that Prabhupāda's teachings unequivocally support a socially egalitarian worldview. Rather, I seek to demonstrate that there are conceptual resources within ISKCON that practitioners within the institution can draw upon in order to justify such a socially egalitarian worldview, even in the face of interpretations to the contrary. 
My second aim in writing this paper is to, by means of socially engaged scholarship, offer a corrective to socially detrimental attitudes, such as patriarchal attitudes, that exist on the broader Hindu landscape. Granted, it is difficult to address all the factors that contribute towards these issues in one fell swoop. However, I argue that locating, retrieving, and emphasizing conceptual resources that (a) have their origins in Hindu thought and (b) can combat these issues, is one step toward curbing such issues. Although this paper focuses primarily on one specific religious tradition (Caitanya Vaiṣnavism), I argue that this paper also serves as a model for other Hindu traditions and can inspire them to develop and apply similar hermeneutical lenses.

At this point, it is worth drawing attention to a logical fallacy known as the "genetic fallacy". When someone discredits something on the basis of its origin or history and not on the basis of its own merits, they are guilty of committing the genetic fallacy. For this reason, I argue that Prabhupāda's hermeneutical lens should be evaluated according to its own merits, and should not be discredited at the outset simply because Prabhupāda himself was known to advocate for views that we would consider antiquated or in tension with contemporary socially progressive values.

Moreover, when I speak of "Prabhupāda's hermeneutical lens", my intention is not to imply that Prabhupāda is the first one to have developed and formulated this lens. Similar hermeneutical lenses have been employed in other contexts, see (Kassam 2014, p. 184). Within India, Jesuit missionaries in the seventeenth century seeking to convert native Hindus employed a similar approach as well (Clooney 1990a). Moreover, Prabhupāda's employment of his hermeneutical lens may have been inspired by other Hindu thinkers, perhaps within his own tradition, although it is unclear precisely where this inspiration originates. For these reasons, when I speak of Prabhupāda's hermeneutical lens, I use this term somewhat loosely to indicate a specific hermeneutical lens that Prabhupāda described and himself employed at various junctures, even though Prabhupāda did not invent this lens per se. Bearing this in mind, I will now proceed to describe this lens.

\section{Understanding Prabhupāda's Hermeneutical Lens}

Prabhupāda's hermeneutical lens can be characterized as an exegetical tool that is shaped by, and which also aids and enhances, the discernment between (a) a religious tradition's doctrinal tenets that are soteriologically ${ }^{1}$ necessary and (b) the details of spiritual praxis that are context-specific. ${ }^{2}$ This hermeneutical lens is highlighted in The Nectar of Devotion, wherein Prabhupāda draws a clear distinction between what he considers to be "basic principles", on the one hand, and particular "details" on the other hand. He explains,

for example, a basic principle is that one has to accept a spiritual master [guru]. Exactly how one follows the instructions of his spiritual master is considered a detail. For example, if one is following the instruction of his spiritual master and that instruction is different from the instructions of another spiritual master, this is called detailed information. But the basic principle of acceptance of a spiritual master is good everywhere, although the details may be different. (Prabhupāda 1998, p. 53)

Thus, as I have just indicated, Prabhupāda's hermeneutical lens acknowledges that there is a vital distinction to be made between soteriologically essential "principles" and context-specific "details" of spiritual praxis. Of course, applying Prabhupāda's hermeneutical lens is done the most effectively when an individual is consciously aware of, and educated about, the soteriologically necessary doctrinal tenets within a particular religious tradition. For this reason, some knowledge of ISKCON's theological framework is first required. Delineating the entire set of soteriologically necessary doctrinal tenets within ISKCON's theological framework would be a lengthy task in itself, and is thus outside the scope of this paper. However, I will provide a brief summation of this framework so that the reader can acquire a general understanding of its soteriologically necessary principles. A concise explanation of ISKCON's orthopraxy is given by Rūpa, whose theological views 
inform much of ISKCON's theological framework as well as Prabhupāda's own theological perspectives (Gosvāmin and Prabhupada 1998, pp. 1-2). In his work titled the Bhaktirasāmrtasindhu (henceforth $B R S$ ), Rūpa, purportedly citing from a Hindu scriptural text, Pādmapurāna (c. 4th to 6th century CE), states, "Viṣnu [Kṛṣna] is always to be remembered and never to be forgotten. All prescriptive rules and prohibitions should serve these two principles" (BRS 1.2.8 ${ }^{3}$ ). Thus, the primary aim of a practicing spiritual practitioner within ISKCON is to cultivate a continuous, loving remembrance (smarana) of Krsna.

By continually remembering Kṛnna with love and by performing various devotional activities, such as hearing (śravana) and glorifying (kïrtana) him, one can enhance one's devotion (bhakti) for Krṣna (BhP 7.5.23 ${ }^{4}$ ). A more comprehensive list of different devotional activities that one can perform is mentioned by Rūpa Gosvāmin in the BRS, which lists 64 components (angas) of bhakti (BRS 1.2.74-245 $5^{5}$. Through the performance of such devotional activities, the spiritual practitioner can awaken pure, unselfish love of Krṣna (preman), the attainment of which is considered to be soteriological perfection. Thus, within ISKCON's theological framework, the ultimate soteriological aim is to love Kṛna purely without any ulterior motives, and ISKCON's various spiritual disciplines and scriptural imperatives are solely intended to lead practitioners toward this goal. For this reason, preman can be seen as what Klaus Klostermaier terms the "hermeneutical centre", around which ISKCON's textual interpretation and spiritual praxis revolves (Klostermaier 2008). Hence, a soteriologically necessary principle can be viewed as something that enhances a spiritual practitioner's remembrance of Kṛnna. Indeed, as the Caitanyacaritāmrta (henceforth CC) (c. 16th century), a hagiography of Caitanya that serves as one of ISKCON's foundational scriptural texts (Kavirāja and Prabhupāda 1998b, p. 3853), indicates that two of the major principles for a spiritual practitioner are to desire whatever is favorable for one's devotion to Krṣna and to avoid whatever is unfavorable for one's devotion to Kṛ̣na $\left(C C 2.22 \cdot 100^{6}\right)$. However, the particularities concerning how Kṛnna-bhakti is to be cultivated and performed should be considered to be context-specific praxic details. In this connection, it is also worth pointing out that in his Upadeśämrrta, Rūpa cautions spiritual practitioners about the dangers of insisting on following certain scriptural prescriptions (niyama-āgraha) when it is unhelpful to do so $\left(\right.$ Up $\left.2^{7}\right)$.

Prabhupāda concretely demonstrated how his hermeneutical lens can be applied with his adjustment of some traditional gender norms concerning the intermingling of men and women within ISKCON. In one instance, Prabhupāda observes that certain individuals with a socially conservative mindset ${ }^{8}$ had criticized him for allowing his male and female students to intermix freely in Europe and America (Kavirāja and Prabhupāda 1998a, p. 835). Prabhupāda states that such individuals had failed to consider that "one cannot suddenly change a community's social customs" (Kavirāja and Prabhupāda 1998a, p. 835). Indeed, elsewhere, Prabhupāda states that the practice of Kṛna-bhakti should be developed according to the contingencies of "deśa-kāla-pätra (the place, the time and the recipient)" (Kaviräja and Prabhupāda 1998a, p. 842), and this is a notion that echoes A.K. Ramanujan's claim that certain dimensions of Hindu thought and religious praxis are context-specific (Ramanujan 1989, p. 53). Prabhupāda explains that "stereotyped" gender norms can never help to spread devotion to Kṛ̣na within the Western countries (Kavirāja and Prabhupāda 1998a, p. 835), thus reinforcing the motif that the performance of Krṣna-bhakti should be adapted to one's particular sociocultural historical contexts in order for its propagation and cultivation to be effective.

Prabhupāda also describes the benefits of allowing both men and women to perform ISKCON's missionary activities. He explains that he instructed both men and women about how to proselytize ISKCON's theology, and, as a result, both men and women have been able to propagate ISKCON's teachings with "redoubled strength" (Kaviräja and Prabhupāda 1998a, p. 842). Prabhupāda also states that he finds the combined preaching efforts of his male and female students to be "wonderful" (Kavirāja and Prabhupāda 1998a, p. 842), thus implying that making praxic adjustments that allowed women in the Western countries to propagate and practice Kṛ̣na-bhakti according to their country's social 
conventions produced more favorable results than imposing on them restrictions such as some of the patriarchal Indian customs of his time.

Prabhupāda's modification of gender roles is worth highlighting because it challenges some prevalent patriarchal attitudes within Hindu thought that are commonly associated with stri-dharma. Stri-dharma can be loosely translated as the duties of women, and patriarchal interpretations of stri-dharma defined women's roles as servants of their husbands and as domestic caretakers (Lipner 2012, p. 116). Presently, patriarchal and androcentric attitudes still persist amongst men in India. For instance, as Subhadra Mitra Channa states, "one of the biggest contradictions in Indian society today is that the ideals of womanhood have not been transformed to include the modern woman. For a majority of Indian men, the ideal is still their mother" (Channa 2013, p. 178). Thus, Prabhupāda's de-emphasis of the religious importance of patriarchal attitudes is highly significant because it indicates that a patriarchal interpretation of stri-dharma is not a soteriologically essential principle within ISKCON's theological framework but is instead a context-specific detail, which can be disregarded if it turns out not to be conducive to one's performance of Kṛ̣na-bhakti.

\section{Strī-Dharma in the Bhāgavatapurāna}

Having described Prabhupāda's hermeneutical lens, I will now explore the wider implications of this lens by analyzing how it can be applied to certain scriptural texts. Specifically, I will turn my attention to the BhP. The BhP emphasizes the worship of Kṛna (Gupta and Valpey 2013, p. 2), whom BhP 1.3.28 regards as the supremely personal God.9 For this reason, the $B h P$ is a central text for many Vaisnava traditions that are devoted to Kṛṣna, including, but not limited to, the Caitanya Vaiṣnava tradition. ${ }^{10}$

Within the $B h P$, there is one narrative that suggests that a patriarchal interpretation of stri-dharma is evaluated as a context-specific praxic detail. This narrative describes Kṛṣna's satisfaction with the devotion of the wives of ritually minded brähmanas ${ }^{11}$ as well as his subsequent blessings upon them. The story begins with Krṣna asking his friends to beg for some food in his name and in the name of his brother (Balarāma) from some brähmanas who were performing a sacrifice (BhP 10.23.3-4). However, the brähmanas ignored Kṛṣna's friends' request for food (BhP 10.23.9). The BhP adds that the brāhmanas had insufficient intelligence and did not consider Krṣna to be the fullness of God, instead regarding him as an ordinary human (BhP 10.23.11 12 ). When Krṣna's friends returned to him without any food, Krṣna asked them to instead ask the wives of the brähmanas for food (BhP 10.23.14). Upon hearing that Kṛ̣na was hungry, the wives rushed towards Kṛ̣na with containers of food (BhP 10.23.19-20). Although these women's husbands, brothers, relatives, and sons sought to prevent them from seeing Kṛnna, the women persisted nevertheless, for their hearts had been drawn to Kṛ̣na by having heard about him repeatedly (BhP 10.23.19-20). The women's insistence on meeting Krṣna against their family's wishes is notable because it signifies a departure from the social constraints imposed upon women by patriarchal understandings of stri-dharma. In fact, when the women arrived in the presence of Krṣna, he initially remarked that their wish to see him was proper (upapanna) (BhP 10.23.25 $5^{13}$ ), even though they had acted contrary to a patriarchal interpretation of stri-dharma.

Krṣna then insisted that the women should return to their families (BhP 10.23.28). However, Krṣna's reasoning for this exhortation is significant. He mentions that if the women stayed in his physical presence, then (1) it would not be pleasing in the sight of the people of this world and (2) it would not be conducive for developing their love for Kṛ̣na, since meditation upon Kṛṣna is a quick method of attaining the love of Kṛ̣na (BhP 10.23.32 ${ }^{14}$ ). Thus, there is no indication in the BhP that Kṛnna wanted the wives to go back to their families because performing domestically inscribed duties was required for their attainment of soteriological perfection.

I will revisit these points shortly, but before doing so, I will finish narrating this story. Seeing their wives' devotion, the brähmanas condemned themselves for their lack of devotion towards Krṣna (BhP 10.23.39). They then contrasted their own spiritual ignorance with the devotion of their wives (BhP 10.23.42-44), thus signifying that their wives were 
spiritually superior to them. Hence, in this narrative, it is the women, who failed to act in accordance with patriarchal interpretations of stri-dharma, who are glorified for their devotion towards Krṣna, and not the men, who were instead preoccupied with the performance of ritual, which, notably, was their worldly dharma as priests and upholders of the Vedic cosmos. Thus, the glorification of the women illustrates that in the BhP, it is ultimately the cultivation of loving devotion, and not simply the performance of domestic duties, that can win the favor of Kṛna. Indeed, the soteriological superiority of bhakti over worldly dharma is a recurring theme throughout the $B h P$ and is also seen in the famous narrative of the rāsa-lillā, or namely, Krṣna's moonlight tryst with the cowherd girls (gopiss) of Vraja (Schweig 2002, pp. 435-39).

However, in this particular narrative of the $B h P(10.23 .3-10.23 .44)$, we observe that Kṛṣna nevertheless insists that the women continue to perform their worldly obligations. As mentioned previously, Kṛ̣na's reasoning is that (1) the women's abandonment of their domestic duties would not be pleasing to the people of this world, thus signifying Kṛṣa's concern with the maintenance of the social order, and (2) the women could make quick progress towards soteriological perfection even without physical proximity to Krṣna.

With regard to (1), it is important to bear in mind that within the context of this specific narrative, the prevailing social attitude is patriarchal, and thus, the women's abandonment of their domestic duties would upset the social order and lead to worldly confusion. Yet, this does not indicate that the women's adherence to a patriarchal interpretation of stri-dharma is soteriologically essential but only socially salutary in some specific circumstances. Thus, in contexts where the prevailing social atmosphere does not encourage such interpretations of stri-dharma, there would be no scripturally rooted incentive to promote an adherence to it.

Moreover, Kṛnna's statement in BhP 10.23.32 that the women could make quicker soteriological progress while they are physically distant from him does not promote a patriarchal interpretation of stri-dharma either. In this verse, Krșna specifically recommends that the brāhmanas' wives should focus their minds on him, and I argue that this meditative practice does not necessitate that the women adhere to a patriarchal interpretation of stri-dharma, since even if the wives are at home, they need not perform the domestic duties enjoined by such an interpretation of stri-dharma. Furthermore, the BhP holds that a devotee's love of Kṛnna can be intensified when they are separated from Kṛ̣na's physical presence. For instance, $B h P$ 10.32.20 $20^{15}$ states:

$\mathrm{O}$ friends, in order to increase their yearning for me, I [Kṛṣna] may not immediately share my love even with those who share their love with me. When a poor person obtains wealth and then loses it, they know nothing other than that wealth, and their minds are filled with anxiety. Similarly, a devotee who becomes separated from me can think of nothing other than me.

Thus, when we take other devotional motifs within the BhP into consideration, one plausible interpretation as to why Kṛnna asked the wives of the brähmanas to leave him is that their love for Kṛnna would become even more intensified if they were physically separated from him. Yet, such separation does not necessitate any rigorous adherence to a patriarchal interpretation of stri-dharma in contexts outside of this particular narrative.

\section{Understanding the Reformative Efficacy of Prabhupāda's Hermeneutical Lens}

However, we may note that there is one limitation to Prabhupāda's hermeneutical lens' ability to facilitate religious reform. As we have seen in the narrative of the brähmanas' wives, these women were still compelled to return to their homes to discharge their domestic and family obligations there, despite the spiritual glory they received by temporarily abandoning these dharma-shaped obligations in order to devotedly serve food to Kṛnna. Moreover, as Tracy Coleman points out, within the BhP, the celebrated episode of the rāsa-lìlă, or the moonlight tryst of gopis of Vraja with Kṛ̣na, also contains a similar motif. Though the gopis initially abandon their worldly obligations and experience intimate union with Kṛ̣na, they are nevertheless exhorted by him to return to their worldly obligations, 
thus leading Coleman to conclude that women are ultimately "powerless to resist the forces of social convention for more than a brief moonlit tryst" (Coleman 2010, pp. 410-11). Furthermore, in other on-the-ground contexts, medieval Vaisnava groups often adopted "the restrictions of the orthodox [caste system] [in order to find] acceptance within the broader Hindu social structure" (Hopkins 1998, p. 14). For instance, some Caitanya Vaiṣnava communities in the 16th century have observed socio-ritual norms concerning caste restrictions, such as not marrying or dining outside of one's caste, in order to maintain social cohesion within their broader social-cultural milieus (O'Connell 1993, p. 23). Thus, the application of Prabhupāda's hermeneutical lens can be of limited efficacy when applied in contexts where spiritual practitioners are bound to follow certain styles of social conventions, even when such conventions are ultimately unnecessary for the attainment of soteriological perfection.

I acknowledge that while Prabhupāda's hermeneutical lens can be employed in order to initiate and achieve religious reform, the degree to which this reform can be concretely realized is largely contingent on the sociocultural sensibilities of individuals within a religious tradition's surrounding environment. However, it worth highlighting that there are instances within history where religious traditions, such as the Vaisnava traditions, challenged the contemporary sociocultural norms of their time. For instance, from the 16th to the 18th century $\mathrm{CE}$, the Caitanya tradition was able to give women a greater status in society, relative to the sociocultural norms of the time, by granting them the ability to function as spiritual teachers (gurus) ${ }^{16}$ (Chakravarti 1985, p. 174; Brzezinski 1996, pp. 73-74), thus supporting Rodney Stark's claim that "new religious movements are likely to succeed to the extent that they maintain a medium level of tension with their surrounding environment-[they] are strict, but not too strict" (Stark 2005, p. 120). As Lauren Iannaccone indicates, the "strictness" in his claim indicates the degree that a religious tradition maintains "a separate and distinctive life style of morality in personal and family life, in such areas as dress, diet, drinking, entertainment, uses of time, sex, child rearing, and the like" (Iannaccone 1994, p. 1190; cited in Stark 2005, p. 120). Conversely, Iannacone notes that "a group is not strict to the degree that it affirms 'the current ... mainline life style in these respects" (Iannaccone 1994, p. 1190; cited in Stark 2005, p. 120). Therefore, in instances where its surrounding environment is reluctant to award women egalitarian rights, we may infer that a religious tradition might be able to grant a greater degree of these rights to women than what this environment promotes, provided that tensions between the movement and the environment remain medium. In such contexts, I argue that Prabhupāda's hermeneutical lens can still be helpful for initiating or generating religious reform.

To bring my discussion of Prabhupāda's hermeneutical lens around in full-circle, I will now turn my attention to how this lens can be applied within ISKCON in particular. Since its inception, ISKCON has witnessed the prevalence of misogynistic attitudes in places such as North America and Europe. These attitudes have led Kim Knott to claim that "women's issues are second only to ISKCON's crisis of leadership in threatening the movement's future" (Knott 1995, p. 116). Starting in the mid-1970s and continuing up to present times, some men within ISKCON have become more intensely patriarchal in their outlooks and have marginalized the role of women within its social spaces (Rochford 2007, p. 116). As this paradigm of male chauvinism grew, certain men in positions of leadership wanted to disempower the women who participate within ISKCON as spiritual practitioners. Thus, from the 1980s to the early 2000s, they instituted several institutional changes that restricted women's institutional and spiritual roles. For instance, they (a) segregated the temples by gender, thus forcing women to stay in the back of the main temple rooms during worship services, (b) forbade women from leading kìrtanas (musical glorification of Kṛnna's auspicious names), and (c) prevented women from occupying pedagogical as well as managerial roles (Rochford 2007, p. 117). Women's "intelligence, motives and capabilities" were also routinely criticized or dismissed in the public lectures given by ISKCON male leaders (Dasi and Dasi 2000, p. 2). Thus, women were projected as "unintelligent", individuals whose presence was "spiritually dangerous" to men, and who 
had little scope to perform activities beyond their domestic and family duties (Whitworth and Shiels 1982, p. 161). According to one ISKCON woman who experienced these forms of misogyny:

I've never so much regretted being born in a woman's body since I joined [ISKCON]. I've never been so much criticized, abused, slandered, misunderstood, or chastised because I have this woman's body. It makes it very difficult to do my service and/or assist others with their service if they are always thinking about these bodily designations instead of the constructive things I could do or say to help them in their service and to help this movement go forward. If you are a single woman [brahmacārin̄i ], every man thinks he is an authority and will yell at you if he feels like it. But it's worse when you're married, because you have one authority and you have to surrender to his inflexible, lord-it-over nature whether he is right or wrong and whether he is nice or cruel about how he relates to you. (Dasi 1999)

Thus, many women devotees within ISKCON were denied equal social and spiritual rights and were instead subordinated to male authority figures, who have evidently failed to give them the proper respect that they deserve. The discrimination that they have faced in ISKCON has seriously hampered their ability to cultivate bhakti. In one survey conducted in the late 1990s, an astounding 67\% of women strongly agreed that sexism within ISKCON is a barrier to their soteriological advancement (Rochford 2007, p. 123). Therefore, as ISKCON's history since the 1970s demonstrates, it has been afflicted with various strands of misogyny that seek to confine women to the roles traditionally ascribed to them in patriarchal interpretations of stri-dharma. These patriarchal attitudes, though less pronounced than they were in the past, still linger today. For instance, ISKCON is still reluctant to allow women to serve as gurus who initiate individuals into the institution (dìkșa-guru). Although ISKCON has recently passed a resolution in October 2019 allowing women to act as $d \bar{\imath} k s \underline{a}$-gurus, at the time of writing, there are still no women who have stepped forward to accept this role. Thus, there is an urgent need within ISKCON for initiating and sustaining women-empowering reform. I argue that one conceptual vehicle for generating and advancing this reform is Prabhupāda's hermeneutical lens, which can serve as a corrective to ISKCON's misogynistic strands by reimagining ISKCON's theological framework in a socially beneficial manner that would be suitable for current times.

For instance, as I have previously argued, according to the BhP and to Prabhupāda, the traditional gender roles that certain men within ISKCON insist on confining women to are not soteriologically necessary but are instead context-specific praxic details. With this understanding, I argue that there is no legitimate theological basis for the subordination of women within ISKCON in Europe and North America to the authority of males within domestic spheres. If one seeks to argue that women should perform the activities directed by a patriarchal interpretation of stri-dharma in order to maintain social order, then, given the social conditions of many present-day sociocultural contexts in social spaces such Europe and North America, this argument is unpersuasive because the contemporary social climate has acknowledged, at least to a greater extent than, say, the sociocultural universe of the BhP, that a woman's domain of agency, authority, and influence can extend beyond the home. If one puts forth the argument that the discharge of domestic duties enables women to make quicker soteriological progress, then, in the light of the abovementioned narrative of the brāhmanas' wives and Prabhupāda's own example of not upholding a patriarchal interpretation of stri-dharma in the Western countries, this argument also fails to deliver the desired conclusion. Even if there are certain women who may feel that discharging domestic duties is more favorable for their cultivation of Krṣna-bhakti, this does not mandate that all women should discharge such duties. Finally, if one argues that women should adhere to a patriarchal interpretation of stri-dharma because this is what Prabhupāda seemed to advocate in his teachings, then this view is problematic since (a) Prabhupāda, in his personal dealings with his female disciples, did 
widen the scope of women's activities to extend beyond the domestic sphere, and because (b) maintaining this view requires the assumption that Prabhupāda's views are static and that Prabhupāda, if alive today, would hold the same socially conservative views that he did over forty years ago. However, given that Prabhupāda did exhibit a certain degree of flexibility by not rigidly sticking to the patriarchal gender roles he was accustomed to in India, (b) seems implausible to maintain. At the least, if a practitioner within ISKCON wishes to adopt a more egalitarian worldview, I argue that the case for $(b)$ is insufficient to persuade such a practitioner to abandon holding on to such a worldview, especially in the light of Prabhupāda's hermeneutical lens.

For these reasons, I argue that when Prabhupāda's hermeneutical lens is properly applied, women should be free to adopt and cultivate whatever role they feel is most suitable for their soteriological advancement, whether this role lies within or outside the domestic sphere.

\section{Exploring the Relevance of Prabhupāda's Hermeneutical Lens Outside ISKCON}

I now argue that the application of Prabhupāda's hermeneutical lens is not limited to ISKCON, nor is it limited to the empowerment only of women. ISKCON can serve as a conceptual microcosm that illustrates some of the issues that are present within larger sociocultural macrocosmic realms. I thus suggest that Prabhupāda's hermeneutical lens has relevance for other Hindu traditions.

To begin with, Prabhupāda's hermeneutical lens can be applied within other Vaiṣnava traditions. As I have argued, the BhP does not value the discharge of domestic duties as a soteriologically necessary principle. With this awareness in mind, the Vaiṣnava traditions whose scriptural foundations include the BhP can draw upon this text's evaluation of a woman's duties to assess whether or not an adherence to a patriarchal interpretation of stri dharma is truly soteriologically necessary. However, in order to draw any conclusions about the applicability of Prabhupāda's hermeneutical lens to the Vaișnava traditions, it would be necessary to critically examine all the foundational scriptural texts and the theological frameworks of such traditions in order to ascertain whether or not these traditions consider a strict adherence to a patriarchal interpretation of stri-dharma to be a requirement for women to attain soteriological perfection. For instance, some Vaiṣnava traditions such as the Vallabha tradition do place a distinctive emphasis on the cultivation of bhakti through the social role of a householder, and this emphasis given to the householder may shift this tradition's views on strī-dharma (Klostermaier 2007, p. 213).

Nevertheless, if this examination was conducted and it revealed that a patriarchal interpretation stri-dharma is not, in fact, a soteriological necessary principle for at least some of these traditions, this discovery would have major implications for Hindu praxis since devotional traditions like Vaișnavism have exerted a continual influence on India's religious landscapes since the early modern period (c. 15th-16th century CE) (Plau 2019, p. 34). An awareness that a patriarchal interpretation of stri-dharma is only a context-specific praxic detail, if this indeed turns out to be the case, would thus provide a theological justification for empowering women within contemporary Hindu milieus by enabling them to occupy the societal roles that are the most conducive for their performance of bhakti.

Moreover, within broader Hindu contexts, Prabhupāda's hermeneutical lens is a particularly helpful tool for social reform because it can lead to critical reflection on the authority of the classical Sanskrit texts that have shaped various Brahminical notions of Hinduism. As Anantanand Rambachan notes, "as long as the values of the Sanskrit texts are held to be normative, these texts cannot be ignored and will have to be engaged in critical dialogue" (Rambachan 2014, p. 92). While Prabhupāda's hermeneutical tool does not deny the epistemic authority of the classical Sanskrit texts, it can foster certain forms of critical dialogue that would question the particular sociocultural values that these texts embody or promote, such as patriarchal interpretations of stri-dharma.

Furthermore, Prabhupāda's hermeneutical lens can be utilized to address other forms of oppression within Hindu contexts. For example, caste oppression is still prevalent within 
India, and as recently as 2016, an Indian Ph.D. student named Rohith Vemula committed suicide due to the discrimination he had experienced because of his lower caste status (Divya and Ankur 2019, p. 216). However, in certain interpretations of the Bhagavad Gìtā (c. $500 \mathrm{BCE}-200 \mathrm{CE}$ ) (henceforth $B h G$ ), which is one of the most important Hindu sacred texts, varna, the idealized textual model of caste, is not viewed as soteriologically necessary. For instance, BhG 9.32 states, O Arjuna, those who have resorted to me [Kṛna] can reach the highest destination, even if they are from wicked families, women, vaiśyas, or śüdras [the lowest caste]". ${ }^{17}$ While it is beyond the scope of this paper to draw a definitive conclusion as to whether or not one's membership in a particular caste is soteriologically necessary for the Hindu traditions that adhere to the $B h G$, it is worth reinforcing that verses such as $B h G$ 9.32 do support the thesis that members of all castes can attain soteriological perfection. At the very least, if there are Hindu traditions that wish to hold to a view of social equality, such readings, when paired with Prabhupāda's hermeneutical lens, could inform their ethical frameworks and assist their attempts to end caste-based oppression. Prabhupāda's hermeneutical lens could be used similarly to combat racism. While it is also beyond the scope of this paper to examine the relationship between one's membership in a racial group and their ability to attain liberation within Hindu traditions, I can briefly note that Hindu traditions that do not ascribe any meaningful soteriological role to one's race could also draw upon Prabhupāda's hermeneutical lens in order to support a view of racial equality.

Finally, I argue that Prabhupāda's hermeneutical lens can improve the conditions of Indian society at large. For example, as Werner Menski mentions, despite the adoption of the Constitution of 1950, the values and customs of many Hindus are heavily influenced by their religious values (Menski 2019, p. 257). Thus, if Prabhupāda's hermeneutical lens can assist Hindus with their creative interpretations and reconfigurations of religious values, this process can in turn guide the reformulation of the customs and the values of Hindus in India, whose ethical frameworks and quotidian behavior are not shaped solely by legal policies that have been adopted by the Indian government.

\section{Conclusions}

I have argued in this paper that an application of Prabhupāda's hermeneutic lens can facilitate religious reform within ISKCON and Hindu thought by enabling individuals to distinguish between socioculturally contingent and context-specific details of praxis and soteriologically essential doctrinal tenets that must be carefully adhered to even on shifting sociocultural landscapes. While I have focused my attention primarily on patriarchal attitudes, I believe that there is scope to apply Prabhupāda's hermeneutical lens to address a wide variety of other social concerns, such as the mistreatment of LGBTQ individuals or individuals of a lower caste status. However, attempting to address such concerns is beyond the scope of this paper.

Funding: This research received no external funding.

Conflicts of Interest: The author declares no conflict of interest.

\section{Notes}

1 I use the term "soteriology" in a broader sense outside of a strictly Christian context to encompass various notions of emancipation from this world, whether it be in Hindu, Christian, Buddhist, or other instances.

2 It is worth briefly noting that similar hermeneutical approaches have been developed in Islamic thought as well. See (Kassam 2014, p. 184).

3 smartavyah satatam viṣnur vismartavyo na jātucit/sarva-vidhi-niṣedhāh syur etayor eva kin̄karāh // (Gosvāmin and Das [1946] 1979).

4 śravanạ̣ kīrtanaṃ viṣnoh smaranạ̣ pāda-sevanam/arcanaṃ vandanạ̣ dāsyạ̣ sakhyam ātma-nivedanam //.

5 guru-pādāśrayas tasmāt krṣna-dīksāadi-śiksanam/viśrambhena guroh sevā sādhu-vartmānuvartanam // sad-dharma-prcchā bhogādi-tyāgah krṣnasya hetave/nivāso dvārakādau ca gañgāder api sannidhau // (Gosvāmin and Das [1946] 1979).

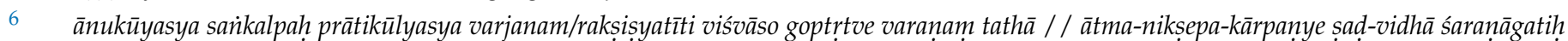
/// (Kavirāja and Prabhupāda 1998b, p. 3834). 
atyāhārah prayāsaś ca prajalpo niyamāgrahah/jana-sangaś ca laulyaim ca șaḍbhir bhaktir vinaśyati // (Gosvāmin and Prabhupada 1998, p. 14). The compound niyamägrahah can be broken apart into either (a) niyama-agraha (failing to grasp scriptural prescriptions) and (b) niyama-ägraha (holding onto scriptural prescriptions when they are not helpful).

8 It can be implied that these individuals were from India during Prabhupāda's time, where such norms would have been more common.

9 In this paper, my references to the $B h P$ are from (Tagare 1950), unless a reference to the original text is given, in which case, I cite from (Śāstrī 1965-1975).

10 For instance, the BhP occupies a central role within the Vaisnnava traditions of both Madhva (c. 13th century CE) and Vallabha (c. 1479-1531 CE) (Okita 2014, pp. 64-65; Redington 2013, pp. 76-78).

nāhaì tu sakhyo bhajato 'pi jantūn bhajāmy amīṣām anuv̛rtti-vrttaye/yathädhano labdha-dhane vinaște tac-cintayānyan nibhṛto na veda //.

16 To understand the extent to which gurus are revered within Hindu contexts, see (Gonda 1965, p. 240; Forstheofel and Humes 2005, p. 3).

17 māṃ hi pārtha vyapāśritya ye 'pi syuh pāpa-yonayah/striyo vaišyās tathā śūdrās te 'pi yānti parām gatim // (Schweig 2007, p. 303).

\section{References \\ Primary Sources}

BhP.

Bhāgavata Purāna.

BhG.

Bhagavad Gìtā.

BRS.

Bhakti-rasāmṛta-sindhu of Rūpa Gosvāmin.

CC.

Caitanya-caritāmrta of Kṛ̣ṇadāsa Kavirāja.

Up.

Upadeśāmrta of Rūpa Gosvāmin.

Gosvāmin, Rūpa, and A. C. Bhaktivedanta Swami Prabhupada. 1998. trans. and commentator. The Nectar of Instruction [Upadeśamrta]. Los Angeles: Bhaktivedānta Book Trust.

Rūpa Gosvāmin, and Haridas Das, transs. 1979, Bhaktirasāmrtasindhu with Commentaries of Jī̌a Gosvāmin, Mukunda Dāsa Gosvāmin, and Viśvanātha Cakravartin. Navadvīpa: Haribol Kutir. First published 1946.

Kavirāja, Kṛ̣nadāsa, and A. C. Bhaktivedanta Swami Prabhupāda. 1998a. trans. and commentator. Caitanya-Caritāmrta: Ādi-Līlā. Los Angeles: Bhaktivedanta Book Trust.

Kavirāja, Kṛ̣ṇadāsa, and A. C. Bhaktivedanta Swami Prabhupāda. 1998b. trans. and commentator. Caitanya-Caritāmrta: Madhya-Līlā. Los Angeles: Bhaktivedanta Book Trust.

Prabhupāda, Swami. 1998. Nectar of Devotion. Los Angeles: Bhaktivedanta Book Trust.

Śāstrī, Kṛ̣nnaśañkara, ed. 1965-1975. Bhāgavata Purāna, with Multiple Sanskrit Commentaries. 13 vols, Ahmedabad: Śrī Bhāgavatavidyāpịtha.

Schweig, Graham. 2007. Bhagavad Gita: The Beloved Lord's Secret Love Song. New York: Harper One.

Ganesh V. Tagare, trans. 1950, Shastri, J. L., ed. Bhägavata Purāna Parts 1-5. Delhi: Motilal Banarsidass.

\section{Secondary Sources}

Amador, J. David Hester. 1998. Feminist Biblical Hermeneutics: A Failure of Theoretical Nerve. Journal of the American Academy of Religion 66: 39-57. [CrossRef]

Brown, Sally A. 2011. Hermeneutical Theory. In The Wiley-Blackwell Companion to Practical Theology. Edited by Bonnie J. MillerMcLemore. Chichester: Wiley-Blackwell, pp. 112-22.

Brzezinski, Jan. 1996. Women Saints in Gaudiya Vaisnavism. In Vaisnavĩ: Women and the Worship of Krishna. Edited by Stephen Rosen. Delhi: Motilal Banarsidass Publishers, pp. 59-85.

Chakraborty, Nirmalya N. 2018. Methodology in Indian Philosophy. In The Routledge History of Indian Philosophy. Edited by Purushottama Bilimoria. New York: Routledge, pp. 15-26.

Chakravarti, Ramakanta. 1985. Vaishnavism in Bengal. Calcutta: Sanskrit Pustak Bhandar.

Channa, Subhadra Mitra. 2013. Gender in South Asia: Social Imagination and Constructed Realities. Cambridge: Cambridge University Press. 
Clooney, Francis. 1990a. Roberto de Nobili, Adaptation and the Reasonable Interpretation of Religion. Missiology: An International Review 18: 25-36. [CrossRef]

Clooney, Francis. 1990b. Thinking Ritually: Rediscovering the Pūrva Mìmāmsā of Jaimini. Leiden: Brill.

Coleman, Tracy. 2010. Viraha-Bhakti and Strīdharma: Re-Reading the Story of Kṛ̣na and the Gopīs in the Harivamśa and the Bhāgavata Purāna. Journal of the American Oriental Society 130: 385-412.

Dasi, Pranada. 1999. Do the Women Deserve This? Chakra. Available online: http://www.chakra.org/discussions/IntFeb1204.html (accessed on 17 October 2020).

Dasi, Visakha, and Sudharma Dasi. 2000. Women in ISKCON: Presentations to the GBC, March 2000. ISKCON Communications Journal 8: $1-4$.

Deadwyler, Gabriel. 2004. Race, Monarchy, and Gender: Bhaktivedanta Swami's Social Experiment. In The Hare Krishna Movement: The Postcharismatic Fate of a Religious Transplant. Edited by Edwin F. Bryant and Maria L. Ekstrand. New York: Columbia University Press, pp. 345-90.

Divya, Vaid, and Datta Ankur. 2019. Caste and Contemporary Hindu Society. In The Oxford History of Hinduism: Modern Hinduism. Edited by Brekke Torkel. Oxford: Oxford University Press, pp. 216-38.

Dudney, Arthur. 2018. Hermeneutics: Hindu, Buddhist, and Jaina. In The Routledge History of Indian Philosophy. Edited by Purushottama Bilimoria. New York: Routledge, pp. 373-80.

Fiorenza, Elisabeth Schüssler, ed. 2014. Feminist Biblical Studies in the Twentieth Century: Scholarship and Movement. Atlanta: Society of Biblical Literature Press.

Flood, Gavin. 2016. Hermeneutics. In The Oxford Handbook of the Study of Religion. Edited by Michael Stausberg and Steven Engler. Oxford: Oxford University Press, pp. 150-59.

Forstheofel, Thomas A., and Cynthia Ann Humes. 2005. Introduction: Making Waves. In Gurus in America. Edited by Thomas A. Forstheofel and Cynthia Ann Humes. Albany: SUNY Press, pp. 1-13.

Freschi, Elisa. 2018. Mīmāṃsā. In The Routledge History of Indian Philosophy. Edited by Purushottama Bilimoria. New York: Routledge, pp. 148-56.

Gonda, Jan. 1965. Change and Continuity in Indian Religion. The Hague: Mouton.

Gupta, Ravi M, and Kenneth R. Valpey. 2013. Introduction: Churning the Ocean of Līlā Themes for Bhāgavata Study. In The Bhāgavata Purāna: Sacred Text and Living Tradition. Edited by Ravi M. Gupta and Kenneth R. Valpey. New York: Columbia University Press, pp. 1-18.

Gupta, Ravi M., and Kenneth R. Valpey, eds. 2016. The Bhagavata Purana: Sacred Text and Living Tradition. New York: Columbia University Press.

Gupta, Ravi. 2007. The Caitanya Vaiṣnava Vedānta of Jīva Gosvāmin: When Knowledge Meets Devotion. London: Routledge.

Hopkins, Thomas Johns. 1998. Orthodoxy vs. Devotionalism: Tension and Adjustment in the Vaiṣnava Tradition. Journal of Vaiṣnava Studies 6: 5-15.

Iannaccone, Lauren R. 1994. Why Strict Churches Are Strong. American Journal of Sociology 99: 1180-1211. [CrossRef]

Kassam, Zayn. 2014. Rereading the Qur'ān from a Gender Justice Perspective. In Feminist Biblical Studies in the Twentieth Century: Scholarship and Movement. Edited by Elisabeth Schüssler Fiorenza. Atlanta: Society of Biblical Literature Press, pp. 179-98.

Klostermaier, Klaus. 2007. A Survey of Hinduism, 3rd ed. Albany: SUNY Press.

Klostermaier, Klaus. 2008. The Hermeneutic Circle and the Hermeneutic Centre. In Hermeneutics and Hindu Thought: Toward a Fusion of Horizons. Edited by Rita Sherma and Arvind Sharma. New York: Springer, pp. 81-94.

Knott, Kim. 1995. The Debate About Women in the Hare Krishna Movement. ISKCON Communications Journal 3: 33-49.

Lipner, Julius. 2012. Hindus: Their Religious Beliefs and Practices. Hoboken: Taylor and Francis.

Lorenz, Ekkehard. 2004. Tracing the Origins of Selected Polemical Statements in the Work of A.C. Bhaktivedanta Swami. In The Hare Krishna Movement: The Postcharismatic Fate of a Religious Transplant. Edited by Edwin F. Bryant and Maria L. Ekstrand. New York: Columbia University Press, pp. 112-28.

Maharaj, Ayon, ed. 2020. The Bloomsbury Research Handbook of Vedānta. New York: Bloomsbury.

Menski, Werner. 2019. Hindu Law in Modern Times. In The Oxford History of Hinduism: Modern Hinduism. Edited by Torkel Brekke. Oxford: Oxford University Press, pp. 244-60.

O'Connell, Joseph. 1993. Religious Movements and Social Structure: The Case of Chaitanya's Vaiṣnavas in Bengal. Shimla: Indian Institute of Advanced Study.

Okita, Kiyokazu. 2014. Hindu Theology in Early Modern South Asia: The Rise of Devotionalism and the Politics of Genealogy. Oxford: Oxford University Press.

Plau, Adrian. 2019. Early Modern Hinduism. In The Oxford History of Hinduism: Modern Hinduism. Edited by Torkel Brekke. Oxford: Oxford University Press, pp. 17-34.

Ramanujan, Attipat Krishnaswami. 1989. Is There an Indian Way of Thinking? An Informal Essay. Contributions to Indian Sociology 23: 41-58. [CrossRef]

Rambachan, Anantanand. 2014. A Hindu Theology of Liberation: Not-Two Is Not One. Albany: SUNY Press.

Redington, James. 2013. Vallabha, the Bhāgavata Purāṇa, and the Path of Grace. In The Bhāgavata Purāna: Sacred Text and Living Tradition. Edited by Ravi Gupta and Kenneth R. Valpey. New York: Columbia University Press, pp. 76-90.

Rochford, E. Burke. 2007. Hare Krishna Transformed. New York: New York University Press. 
Sardella, Ferdinando. 2012. Modern Hindu Personalism: The History, Life, and Thought of Bhaktisiddhanta Sarasvati. New York: Oxford University Press.

Schweig, Graham. 2002. Humility and Passion: A Caitanyaite Vaishnava Ethics of Devotion. Journal of Religious Ethics 30: 421-44. [CrossRef]

Sherma, Rita, and Arvind Sharma, eds. 2008. Hermeneutics and Hindu Thought: Toward a Fusion of Horizons. New York: Springer.

Stark, Rodney. 2005. The Rise of Mormonism. New York: Columbia University Press.

Uskokov, Aleksandar. 2018. The Long and Short of It: Mahā-vākya from Mīmāmsā to Jīva Gosvāmin, from the Veda to the Bhāgavata. Journal of Hindu Studies 11: 38-52. [CrossRef]

Whitworth, John, and Martin Shiels. 1982. From Across the Black Water: Two Imported Varieties of Hinduism. In New Religious Movements: A Perspective for Understanding Society. Edited by Eileen Barker. New York: Edwin Mellen Press, pp. 155-72.

Zimmermann, Jens. 2015. Hermeneutics: A Very Short Introduction. Oxford: Oxford University Press. 